\title{
Lymphogranuloma Venereum-Associated Proctitis Mimicking a Malignant Rectal Neoplasia: Searching for Diagnosis
}

\author{
Raquel Pimentel ${ }^{a} \quad$ Catarina Correia $^{a} \quad$ João Estorninho ${ }^{a} \quad$ Elisa Gravito-Soares ${ }^{a}$ b \\ Marta Gravito-Soares ${ }^{a, b}$ Pedro Figueiredo ${ }^{a, b}$ \\ ${ }^{a}$ Department of Gastroenterology, Hospital and University Center of Coimbra, Coimbra, Portugal; b Faculty of \\ Medicine, University of Coimbra, Coimbra, Portugal
}

Keywords

Chlamydia trachomatis - Lymphogranuloma venereum .

Proctitis - Rectal cancer

\section{Abstract}

Background: Chlamydia trachomatis-lymphogranuloma venereum (LGV) is a sexually transmitted infection (STI) and an uncommon cause of proctitis. The diagnosis requires a high index of clinical suspicion, since the clinical, imaging, endoscopic, and histological findings can mimic multiple benign or malignant conditions like inflammatory bowel disease and rectal neoplasms. Case Presentation: We present the case of a 48-year-old Caucasian male with no significant previous medical history who was admitted due to the suspicion of a rectal neoplasia. He underwent an abdominopelvic computed tomography (CT) scan and pelvic magnetic resonance imaging (MRI) before admission due to complaints of anorectal pain, hematochezia, and constipation over the previous 2 weeks. The examination revealed a circumferential rectal wall thickening, infiltration of the perirectal fat and invasion of the mesorectal fascia, associated with perirectal fat lymphadenopathy. A radiological diagnosis of a rectal malignant neoplasia staged as T4N2MX was stated. Digital rectal examination identified a circumferential rectal tumor.
Rectosigmoidoscopy showed an extensive and circumferential ulceration of the rectal mucosa, with elevated geographical borders, exudate, and aphthoid erosions at the proximal limit of the endoscopic mucosal ulceration. Biopsy specimens revealed acute ulcerative proctitis with lymphoplasmocytic inflammatory infiltrate but no evidence of dysplasia or malignancy. A STI screening was positive for HIV-1 (CD4+ $\left.251 / \mathrm{mm}^{3} ; N=700-1,100\right)$ and $C$. trachomatis, with an elevated IgA-specific antibody titer $(52.000 ; N<5.0)$, suggesting LGV disease. The diagnosis was confirmed by the identification of C. trachomatis DNA on rectal swab. Other infectious causes of acute proctitis were excluded. When faced with these results, the patient ended up mentioning that he had unprotected anal sex with men. He started treatment with doxycycline $100 \mathrm{mg}$ twice a day for 21 days, with a drastic improvement. Rectosigmoidoscopy was repeated and showed clear signs of progressive resolution of the ulcerative proctitis. Discussion: LGV-associated proctitis, often undervalued, is a reemerging disease which should always be considered a benign cause of rectal mass, in order to avoid delay in diagnosis and development of complications. Diagnosis becomes more challenging in patients with unknown HIV status. A detailed clinical history, including sexual behaviors, is a vital step to achieve the final diagnosis.

(c) 2021 Sociedade Portuguesa de Gastrenterologia Published by S. Karger AG, Basel

Correspondence to:

Raquel Pimentel, raquelreispimentel@ hotmail.com karger@karger.com www.karger.com/pjg

Karger $\stackrel{\text { ' }}{5}$

BOPEN ACCESS (c) 2021 Sociedade Portuguesa de Gastrenterologia Published by S. Karger AG, Basel

This is an Open Access article licensed under the Creative Commons Attribution-NonCommercial-4.0 International License (CC BY-NC) (http://www.karger.com/Services/OpenAccessLicense), applicable to the online version of the article only. Usage and distribution for commercial purposes requires written permission. 
Proctite por linfogranuloma venéreo mimetizando uma neoplasia maligna do reto: procurar para diagnosticar

\section{Palavras chave}

Chlamydia trachomatis - Linfogranuloma venéreo .

Proctite $\cdot$ Cancro retal

\section{Resumo}

Introdução: A infeção por Chlamydia trachomatis-linfogranuloma venéreo (LGV) é uma doença sexualmente transmissível (DST), sendo uma causa incomum de proctite. O diagnóstico exige um elevado grau de suspeição, dado que os achados clínicos, radiológicos, endoscópicos e histológicos podem mimetizar múltiplas condições benignas ou malignas, como a doença inflamatória intestinal e as neoplasias retais. Caso clínico: Apresentamos o caso de um homem de 48 anos, caucasiano, sem antecedentes relevantes, admitido por suspeita de neoplasia retal. Por queixas de dor anorretal, hematoquézias e obstipação com 2 semanas de evolução, realizou uma tomografia computadorizada abdominopélvica e uma ressonância magnética pélvica, que revelaram espessamento retal circunferencial, infiltração da gordura periretal e invasão da fáscia mesoretal, associados a linfadenopatias locais, sugestivos de malignidade retal (T4N2MX). O toque retal identificou uma tumoração retal circunferencial. A retosigmoidoscopia mostrou mucosa retal com ulceração extensa e circunferencial, bordos geográficos elevados, exsudado e erosões aftóides no limite proximal da ulceração mucosa. As biópsias revelaram proctite ulcerada aguda com infiltrado linfoplasmocitário difuso, sem displasia ou neoplasia. O screening de DST foi positivo para VIH-1 (CD4 $\left.{ }^{+} 251 / \mathrm{mm}^{3} ; \mathrm{N}: 700-1100\right)$ e título elevado de IgA para C. trachomatis $(52000 ; \mathrm{N}<5)$, sugerindo LGV. O diagnóstico foi confirmado pela identificação do DNA de $C$. trachomatis em zaragatoa retal. Outras causas infecciosas de proctite aguda foram excluídas. Perante estes resultados, o doente acabou por mencionar que tinha tido relações homossexuais anais desprotegidas. Iniciou doxiciclina (100 mg duas vezes por dia, por 21 dias) com melhoria sintomática drástica. Repetiu retosigmoidoscopia, com sinais de proctite ulcerada em resolução. Discussão: A proctite por LGV, frequentemente desvalorizada, é uma doença re-emergente, que deve ser sempre equacionada como causa benigna de massa retal, de modo a evitar o atraso diagnóstico e o desenvolvimento de complicações. O diagnóstico torna-se mais desafiante em doentes com status VIH desconhecido. A história clínica detalhada, incluindo comportamentos sexuais de risco, é fundamental para o diagnóstico.

(C) 2021 Sociedade Portuguesa de Gastrenterologia Publicado por S. Karger AG, Basel

\section{Introduction}

Proctitis, an inflammatory syndrome arising in the rectum, is increasing in incidence. Both infectious and noninfectious etiologies may be implicated. Inflammatory bowel disease (IBD), radiation, and diversion proctitis are some of the noninfectious causes [1]. On the other hand, infectious proctitis is also associated with nonsexually transmitted agents such as Escherichia coli, Shigella spp., Campylobacter spp., and Clostridioides difficile. Sexually transmitted agents, such as Neisseria gonorrhoeae, Chlamydia trachomatis, Treponema pallidum, and Herpes simplex virus (HSV) are increasing in prevalence, especially in men who have sex with men (MSM) [1-5].

C. trachomatis is a typical pathogen among patients with sexually transmitted anorectal infections [6]. Although lymphogranuloma venereum (LGV) is an uncommon cause of proctitis, more recently, outbreaks of sexually transmitted infections (STI) have been arising in western Europe. LGV can mimic more common conditions like IBD-related proctitis, other forms of infectious proctitis, and rectal adenocarcinoma or lymphoma [7].

A few cases of misdiagnosis of LGV-related proctitis as a rectal neoplasia were reported in the literature [7-14]. The similarity to rectal cancer presentation can delay the diagnosis, leading to high morbidity [7].

The diagnosis of rectal LGV requires a high index of clinical suspicion. An infectious etiology is usually low on the list of differential diagnoses for a rectal mass, but investigation for LGV should be considered more frequently, especially in high-risk patients such as MSM who are positive for human immunodeficiency virus (HIV) [13, 14].

We present a case of LGV-associated proctitis in a middle-aged man with an unknown sexuality and HIV infection status, initially misdiagnosed as rectal neoplasia based on the clinic and imaging findings. The purpose of this case report is to increase the consciousness for rectal LGV amongst gastroenterologists, surgeons, and radiologists, to facilitate the early diagnosis and appropriate management of these patients. 
Fig. 1. Coronal (a) and axial (b) contrastenhanced abdominopelvic CT images and axial T1 (c) and T2 (d) pelvic MRI showing a diffuse circumferential rectal wall thickening associated with perirectal fat-stranding and lymphadenopathy.
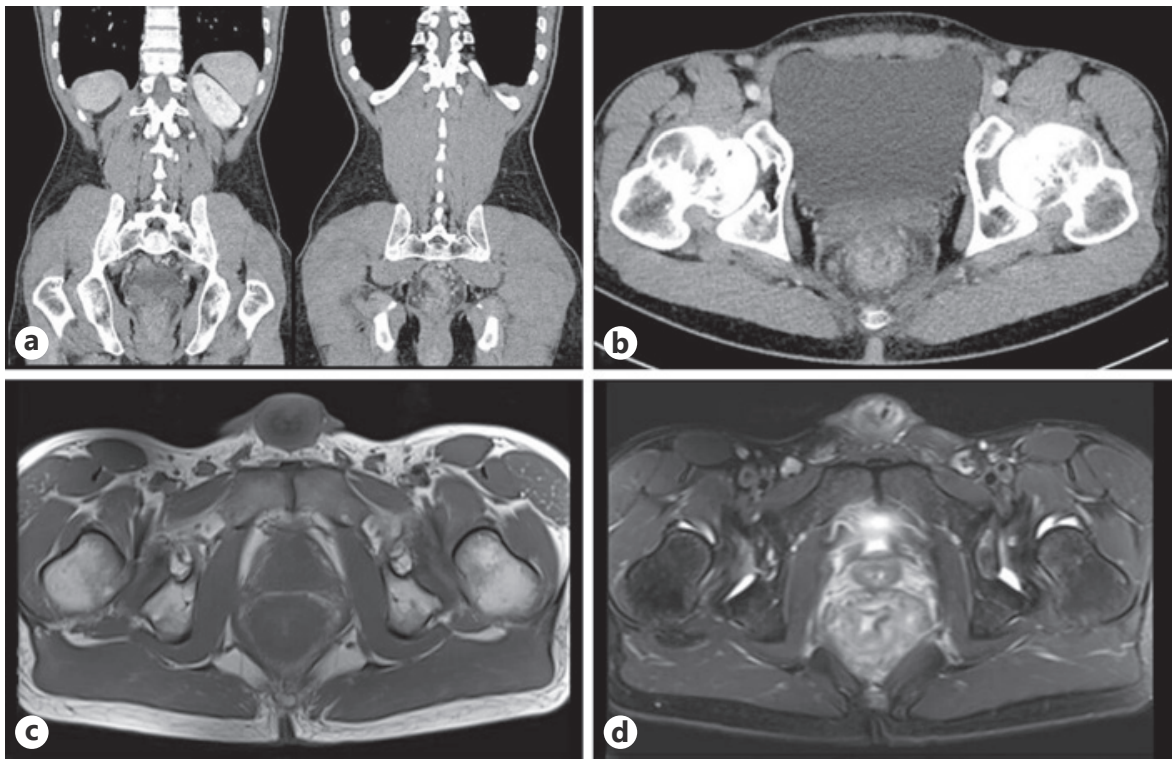

Fig. 2. Endoscopic images showing some aphthoid erosions at the proximal limit reached with the colonoscope (a), and a circumferential ulceration of the rectal mucosa with mucopurulent exudate $(\mathbf{b}, \mathbf{c})$.
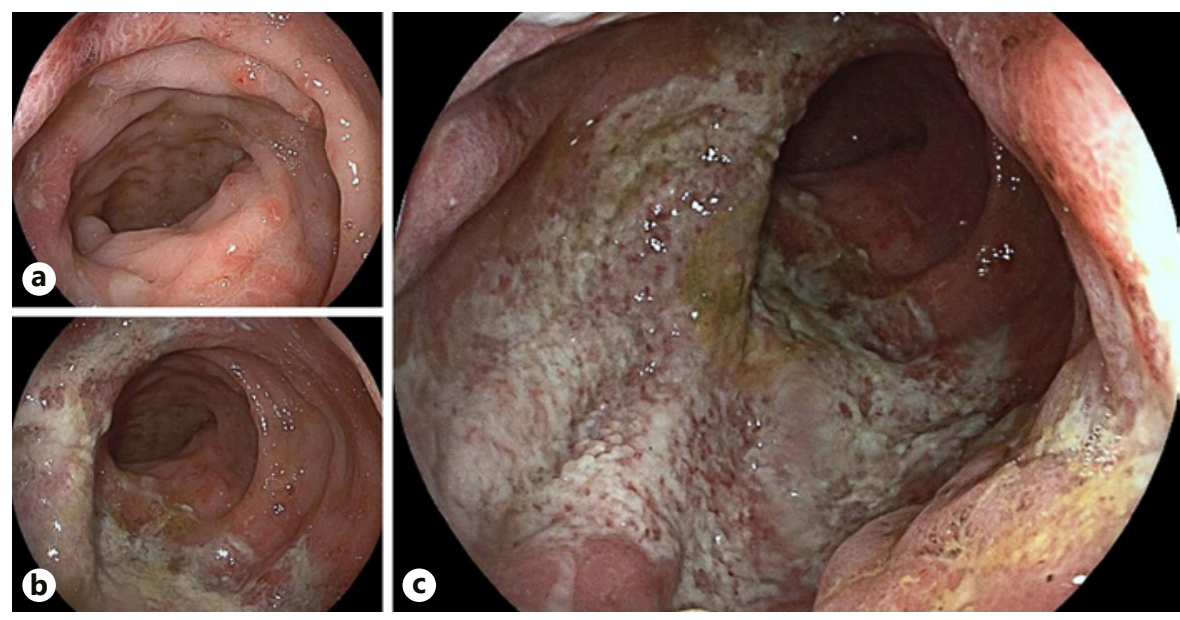

\section{Case Report}

A 48-year-old Caucasian male with no significant previous medical history presented at the surgical emergency department of our hospital due to the suspicion of rectal neoplasia based on the results of an abdominopelvic computed tomography (CT) scan and pelvic magnetic resonance imaging (MRI) performed the day before at another institution. Imaging findings included a circumferential rectal wall thickening, with infiltration of the perirectal fat and invasion of the mesorectal fascia, associated with perirectal fat lymphadenopathy. A radiological diagnosis of a rectal malignant neoplasia staged as T4N2MX was given (Fig. 1).

The patient performed the previous exam due to complaints of anorectal pain, hematochezia, and constipation over the previous 2 weeks. He denied having fever, night sweats, abdominal pain, weight loss, or any other symptoms. He also denied abdominopelvic trauma, recent traveling to tropical destinations, anal sexual intercourse, and a personal or family history of colorectal cancer or IBD. He reported a family history of pancreas neoplasia (in a 2nd-degree relative) and cervical (a 1st-degree relative) and breast (2nd-degree relatives) cancer.

Physical examination was unremarkable and showed hemodynamic stability. Digital rectal examination identified a palpable circumferential rectal mass at $6-8 \mathrm{~cm}$ from the anal verge.

Laboratory results showed a white blood cell count of $8.5 \times$ $10^{9} / \mathrm{L}(N=4.0-10.0)$, hemoglobin $14.3 \mathrm{~g} / \mathrm{dL}(N=13.0-17.5)$, and C-reactive protein $2.52 \mathrm{mg} / \mathrm{dL}(N<0.50)$, with normal liver and renal function. Carcinoembryonic antigen was negative $(3.5 \mathrm{ng} /$ $\mathrm{mL} ; N<5.4)$.

In view of the clinical and imaging findings, the patient was referred to rectosigmoidoscopy that revealed an extensive and circumferential ulceration of the rectal mucosa with elevated geographical borders and exudate. Some aphthoid erosions at the proximal limit of the endoscopic mucosal ulceration were also observed (Fig. 2). 
Fig. 3. Histopathological images showing an acute mucosal ulceration, with reactional changes of the crypts, goblet cell depletion, diffuse lymphoplasmocytic inflammatory infiltrate, and granulation tissue in the lamina propria. HE. a $\times 40$. b $\times 100$. c Immunohistochemistry for cytokeratin AE1/AE3 was negative. $\times 100$.

Fig. 4. a-c Endoscopic images showing complete mucosal healing with scattered scars on the rectal mucosa.
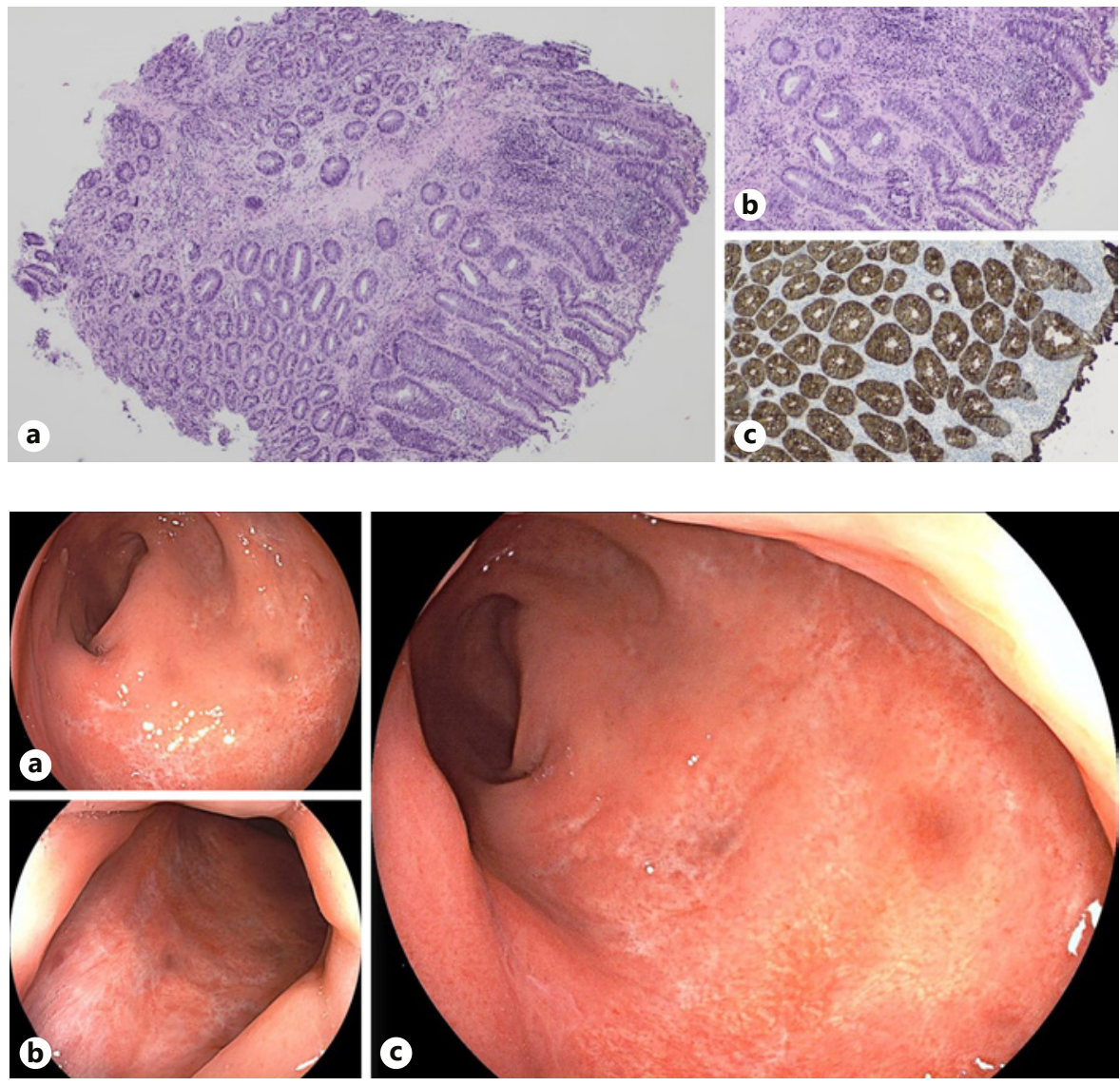

Biopsy specimens showed acute ulcerative proctitis with reactional changes of the crypts, goblet cell depletion, diffuse lymphoplasmocytic inflammatory infiltrate, and granulation tissue in the lamina propria. No microorganisms, spirochetes, or cytomegalic inclusion bodies were identified. Immunohistochemistry for Cytomegalovirus (CMV) was negative. There was no evidence of dysplasia or malignancy in these samples (Fig. 3).

A full STI screening was performed. HIV-1 serology proved positive with CD4+ count of $251 / \mathrm{mm}^{3}(N=700-1,100)$. Additionally, an elevated C. trachomatis IgA-specific antibody titer $(52.000 ; N<5.0)$ suggested LGV disease. The diagnosis was confirmed by C. trachomatis positivity on nucleic acid amplification testing on a rectal swab.

Other infectious causes of acute proctitis, including N. gonorrhoeae, T. pallidum, HSV, CMV, other fecal bacteria, and parasites, were excluded. When faced with these results, the patient ended up mentioning that he had had unprotected anal sex with men before the onset of symptoms.

A diagnosis of LGV-associated proctitis in a newly diagnosed HIV-infected man was made. The patient started treatment with doxycycline $100 \mathrm{mg}$ twice a day for 21 days. He also underwent antiretroviral therapy with bictegravir, emtricitabine, and tenofovir for HIV infection.

His symptoms dramatically improved after beginning antibiotic therapy. Two weeks later, rectosigmoidoscopy was repeated and there were clear signs of a progressive resolution of the ulcerative proctitis. A 3-month follow-up colonoscopy showed complete mucosal healing with scattered scars on the rectal mucosa (Fig. 4).

\section{Discussion}

In this clinical case study, we present a patient with acute proctitis, whose imaging findings raised the suspicion of rectal neoplasia. However, a detailed clinical history combined with endoscopic, histologic, and laboratory results suggested, instead, an infectious etiology, which led to a final diagnosis of LGV-proctitis in a newly diagnosed HIV-infected man.

Infectious proctitis is often sexually acquired. C. trachomatis is one of the most common agents of STIs $[1,2$, $6,15,16]$.

C. trachomatis serovars $\mathrm{A}-\mathrm{K}$ remain confined to the mucosa and are usually associated with a mild inflammatory rectal syndrome, requiring only 1 week of antibiotic therapy. In contrast, L strains are invasive, causing severe ulcerative proctitis, and can disseminate via underlying connective tissue and spread to regional lymph nodes, thus demanding a longer course of antibiotics $[15,17]$.

LGV is a STI caused by L serovars (L1-L3) of C. trachomatis by direct inoculation. The subvariant $\mathrm{L} 2 \mathrm{~b}$ is the causative strain in the majority of cases in Europe [17, 18]. Depending on the site of inoculation, LGV may deter- 
mine inguinal disease (after inoculation via the genitalia or anal area) or anorectal syndrome (after inoculation via the rectum) [17].

Although an uncommon cause of acute proctitis, LGV has become a major cause of sexually transmitted proctitis, being endemic among MSM $[5,6,17]$.

Inoculation via the rectum usually determines an isolated proctitis without lymphadenitis (in $83 \%$ ). Patients can present with a wide range of symptoms including severe anorectal pain, rectal mucopurulent discharge, bleeding per rectum, tenesmus, and constipation due to mucosal and perirectal edema. In cases of severe inflammation, a prominent rectal wall thickening, rectal mass, or lymphadenopathy may occur, mimicking a rectal neoplasia $[2,5,7,9,14,17,19]$.

There are no pathognomonic features of rectal LGV. The clinical, imaging, endoscopic, and/or histological findings may be similar to those caused by IBD and rectal adenocarcinoma or lymphoma. A high degree of clinical suspicion based on a detailed clinical history is essential to achieve the diagnosis of rectal LGV, particularly when a patient's HIV status is unknown [5].

Imaging findings can show a diffuse rectal wall thickening, perirectal fat-stranding, submucosal edema, seminal vesicle enlargement, and pelvic and/or retroperitoneal lymphadenopathy in patients with LGV-proctitis. On the other hand, colorectal cancer can present as a focal or diffuse irregular wall thickening and can spread beyond the rectal serosa [7].

Endoscopic manifestations of LGV-proctitis can range from a mild mucosa erythema and aphtha to circumferential rectal ulcers, with friability and mucopurulent exudate, and tumor-like masses [17, 19, 20].

Histopathological findings of LGV-proctitis include mucosal ulceration, diffuse lymphohistiocytic infiltrate, hyperplasia of lymph follicles, crypt abscesses, or nonnecrotizing granulomatous inflammation $[7,17]$.

Definitive diagnosis of LGV-proctitis relies on the identification of the causative agent. Nucleic acid amplification tests are the current gold standard for the detection of chlamydial infections, with higher diagnostic performance in terms of sensitivity, specificity, and responsetime than the previously used culture and immunological techniques $[2,16,19]$. Different types of samples can be used, such as anogenital lesion (ulcer exudate), rectal swab (when anorectal LGV is suspected), bubo aspirate (suspicion of inguinal LGV), or urine (when inguinal lymphadenopathy is suspected) [16]. If available, genotyping of $C$. trachomatis from the suspected clinical sample where $C$. trachomatis DNA was detected can also be

Lymphogranuloma Venereum-Associated Proctitis performed to identify invasive genotypes (L1-L3) [17]. A presumptive LGV diagnosis can be made based on a $C$. trachomatis IgA-specific antibody test. A significant elevation in antibody titer, particularly IgA anti-major outer membrane protein antibodies, in combination with LGV symptomatology, strongly suggests a diagnosis of LGV $[2,17]$. It is important to highlight that serologic testing has some drawbacks: diagnostic sensitivity and specificity are suboptimal, interpretation for LGV infection is not standardized, the absence of appropriate validation for rectal infections, and an inability to differentiate between past and current infection. Diagnosis of LGV infection based on cell culture methods is now outdated, because it is labor-intensive, expensive, and rarely available, besides having a suboptimal diagnostic sensitivity [17].

HIV infection is strongly associated with LGV transmission, with a prevalence of HIV among MSM with LGV ranging from 67 to $100 \%[17,18]$. Therefore, when a diagnosis of LGV is suspected, it is mandatory to test for HIV and other blood-borne viruses (hepatitis B and hepatitis C) if the serostatus is unknown [17].

Additionally, in case of proctitis in MSM, screening for other STIs is also recommended (including syphilis, gonorrhea, and HSV), as these may be the cause of the proctitis or coexist with LGV [16]. In about $20 \%$ of anorectal infections, $>1$ sexually transmitted agent is observed [6].

LGV-proctitis can be associated with significant comorbidity, including fissure, fistula, abscess, scarring, and stricture. Patients with a clinical syndrome consistent with LGV-proctitis should thus immediately start treatment, even if no LGV diagnostic test is readily available [17]. LGV treatment consists of a course of doxycycline $100 \mathrm{mg}$ twice daily for 3 weeks $[16,17]$. An alternative treatment regimen is azithromycin $1 \mathrm{~g}$ weekly for 3 weeks, but in rectal infections doxycycline achieves higher eradication rates [16].

LGV represents a compulsory notifiable disease. An essential requirement for the management of this STI includes the partner notification. Sexual partners from the last 3 months must be tested and, even if asymptomatic, should be treated with a course of doxycycline $100 \mathrm{mg}$ twice daily for 1 week [17]. Patients should abstain from any sexual contact until they have completed therapy [17].

In anorectal disease, symptoms should resolve within 1-2 weeks from the beginning of antibiotic therapy [17]. In case of complicated disease with fistulas or anal strictures, surgery or aspiration and drainage of lymph nodes may be needed [19].

GE Port J Gastroenterol 2022;29:267-272

DOI: $10.1159 / 000516011$ 
LGV-associated proctitis, often undervalued, is a reemerging disease, which should always be considered a benign cause of rectal mass to avoid a delay in diagnosis and the development of complications. The diagnosis requires a high index of clinical suspicion, since clinical, imaging, endoscopic, and histological findings can mimic multiple benign or malignant conditions such as IBD, rectal adenocarcinoma, and lymphoma. Diagnosis becomes more challenging in patients with an unknown HIV status. A detailed clinical history, including sexual behaviors, is a vital step to achieve the final diagnosis.

\section{Acknowledgement}

The authors would like to thank to João Gama, Rui Almeida, and Caetano Oliveira from the Anatomic Pathology Department of the Hospital and University Center of Coimbra for providing the histopathological pictures.

\section{Statement of Ethics}

Written informed consent was obtained from the patient for publication of this case report and any accompanying images. The authors have no ethical conflicts to disclose.

\section{Conflict of Interest Statement}

The authors have no conflicts of interest to declare.

\section{Funding Sources}

No subsidies or grants contributed to this work.

\section{Author Contributions}

All the authors had a significant contribution in this work, in such a way that they participated sufficiently in the work to assume responsibility for the content. All authors were responsible for the final approval of the submitted version.

\section{References}

1 Voth ML, Akbari RP. Sexually transmitted proctitides. Clin Colon Rectal Surg. 2007 Feb; 20(1):58-63.

2 de Vries HJ, Zingoni A, White JA, Ross JD, Kreuter A. 2013 European Guideline on the management of proctitis, proctocolitis and enteritis caused by sexually transmissible pathogens. Int J STD AIDS. 2014 Jun;25(7): 465-74.

3 Harrison T, Som M, Stroup J. Lymphogranuloma venereum proctitis. Proc Bayl Univ Med Cent. 2016 Oct;29(4):418-9.

4 Levy I, Gefen-Halevi S, Nissan I, Keller N, Pilo $\mathrm{S}$, Wieder-Finesod A, et al. Delayed diagnosis of colorectal sexually transmitted diseases due to their resemblance to inflammatory bowel diseases. Int J Infect Dis. 2018 Oct; 75:34-8.

5 Neri B, Stingone C, Romeo S, Sena G, Gesuale $\mathrm{C}$, Compagno $\mathrm{M}$, et al. Inflammatory bowel disease versus Chlamydia trachomatis infection: a case report and revision of the literature. Eur J Gastroenterol Hepatol. 2020 Mar; 32(3):454-7.

6 Morgado-Carrasco D, Alsina Gibert M, Bosch Mestres J, Álvarez Martínez M, Blanco Arévalo JL, Fuertes de Vega I. Infecciones de transmisión sexual con afectación anorrectal: agentes causales, coinfecciones, infección por el VIH y conductas de riesgo. Med Clin (Barc). 2019 Feb;152(3):98-101.

7 Sullivan B, Glaab J, Gupta RT, Wood R, Leiman DA. Lymphogranuloma venereum
(LGV) proctocolitis mimicking rectal lymphoma. Radiol Case Rep. 2018 Sep;13(6): 1119-22.

8 Alfa-Wali M, Muktar S, Pissas D, Slater C. Unusual case of a rectal tumour. BMJ Case Rep. 2018 Mar;2018:bcr2017223944.

9 Craxford L, Fox A. Lymphogranuloma venereum: a rare and forgotten cause of rectal stricture formation. Int J STD AIDS. 2018 Nov;29(11):1133-5.

10 García-Mayor Fernández RL, Fernández González M, Martínez-Almeida Fernández R. Atypical lymphogranuloma venereum mimicking an anorectal neoplasm. Rev Esp Enferm Dig. 2018 Oct;110(10):676-7.

11 Bancil AS, Alexakis C, Pollok R. Delayed diagnosis of lymphogranuloma venereum-associated colitis in a man first suspected to have rectal cancer. JRSM Open. 2016 Dec; 8(1):2054270416660933.

12 Hechtman JF, Dimaio CJ, Matloff J, Harpaz $\mathrm{N}$, Zhu H. Rectal lymphogranuloma venereum mimicking cancer. Endoscopy. 2013;45 Suppl 2 UCTN:E315-6.

13 Mistrangelo M, Dal Conte I, Gregori G, Castellano I, Famiglietti F, De Vries HJ. Rectal lymphogranuloma venereum. Colorectal Dis. 2012 Nov; 14(11):e792-3.

14 Taylor G, Dasari BV, McKie L, Harvey C, Emerson C. Lymphogranuloma venerum (LGV) proctitis mimicking rectal cancer. Colorectal Dis. 2011 Apr;13(4):e63-4.
15 Ootani A, Mizuguchi M, Tsunada S, Sakata H Iwakiri R, Toda S, et al. Chlamydia trachomatis proctitis. Gastrointest Endosc. $2004 \mathrm{Jul}$; 60(1):161-2.

16 Piñeiro L, Galán JC, Vall-Mayans M. Infections caused by Chlamydia trachomatis (including lymphogranuloma venereum) and Mycoplasma genitalium. Enferm Infecc Microbiol Clin. 2019 Oct;37(8):525-34.

17 de Vries HJ, de Barbeyrac B, de Vrieze $\mathrm{NH}$, Viset JD, White JA, Vall-Mayans M, et al. 2019 European guideline on the management of lymphogranuloma venereum. J Eur Acad Dermatol Venereol. 2019 Oct;33(10):1821-8.

18 Cole MJ, Field N, Pitt R, Amato-Gauci AJ, Begovac J, French PD, et al. Substantial underdiagnosis of lymphogranuloma venereum in men who have sex with men in Europe: preliminary findings from a multicentre surveillance pilot. Sex Transm Infect. 2020 Mar; 96(2):137-42.

19 López-Vicente J, Rodríguez-Alcalde D, Hernández-Villalba L, Moreno-Sánchez D, Lumbreras-Cabrera M, Barros-Aguado C, et al. Proctitis as the clinical presentation of lymphogranuloma venereum, a re-emerging disease in developed countries. Rev Esp Enferm Dig. 2014 Jan;106(1):59-62.

20 Silva JC, Rodrigues A, Carvalho J. Infectious Proctitis due to Chlamydia trachomatis: Venereal Diseases in Proctology. GE Port J Gastroenterol. 2020 Nov;27(6):439-40. 